\title{
Methods for Determining Nitrogen, Phosphorus, and Potassium (NPK) Nutrient Content Using Features from Accelerated Segment Test (FAST)
}

\author{
Raden Sumiharto $^{1}$, Ristya Ginanjar Putra ${ }^{2}$ and Samuel Demetouw ${ }^{3}$ \\ 1, 2,3 Departement of Computer Science and Electronics, Universitas Gadjah Mada, Yogyakarta, DIY, Indonesia \\ ${ }^{1}$ r_sumiharto@ugm.ac.id, ${ }^{2}$ dimas.ristya.g@mail.ugm.ac.id, ${ }^{3}$ samuel.demetouw@mail.ugm.ac.id.com
}

\begin{abstract}
Nutrient Content NPK is macro nutrient content that important for the growth of a plant. The measurement of NPK conducted periodically, but the measurement using laboratories test need relatively long time. This Research is conducted to determine the nutrient content of the soil, consisted of nitrogen, phosphor, and calcium (NPK) using digital image processing based on Features from Accelerated Segment Test (FAST) and backpropagation artificial neural network. The data sample in this research taken from the rice field soil in Daerah Istimewa Yogyakarta province where the soil taken at the length of $30 \mathrm{~cm}$ to $110 \mathrm{~cm}$ with $120 \mathrm{~cm}$ interval, and $-30^{\circ}$ to $30^{\circ}$ degree with interval $10^{\circ}$. The model from this measurement system based on texture's characteristic that extracted using Scale Invariant Feature Transform from soil's image that already passed preprocessing process. The characteristic result will be the input from the artificial neural network with a variation on parameter's model. The model tested for the purpose of knowing the influence the distance and degree where the image taken and the influence of parameter's artificial neural network. The result from the research, is a accurate value of the measurement for each nutrient in the soil, nitrogen (94.86\%), phosphor (58.93\%) and calcium (63.57\%), with the mean $72,46 \%$. The corresponding result obtained from image taken with optimal height of $70 \mathrm{~cm}$ and degree $0^{\circ}$.
\end{abstract}

Keywords: Features, Accelerated Segment, Determining Nitrogen, Phosphorus, Potassium, NPK.

\section{INTRODUCTION}

Land is one of the very basic needs in agriculture. Ideal soil has good nutrients according to the needs of a plant. If a plant lacks a nutrient, it will show symptoms in a specific organ which is usually called a symptom of chastity. Nutrients needed by plants are not entirely able to be fulfilled from the ground. Therefore, it is necessary to add from the outside and usually in the form of fertilizer. Fertilizer is a material that is given into the soil or plants to meet the needs of nutrients for plants and can function to improve the physical, chemical and biological properties of the soil [1]. However, excessive use of fertilizer can be toxic to the soil due to nutrient imbalance. Therefore, the application of fertilizer composition in accordance with the needs of the soil is highly recommended so that the yields become better without damaging the soil [2].

Evaluation of soil fertility can be done in several ways, namely through visual observation of plant deficiency symptoms, plant analysis and soil analysis. Plant analysis includes analysis of primary macro nutrient uptake and vegetative testing of plants by looking at plant growth [2]. Soil analysis can be done by measuring nutrients, which are taking soil samples and brought to the Laboratory.

Measurement of nutrients can also be done by processing digital images and artificial neural networks. Digital image processing can be used to recognize objects in detail. One method of processing digital images is ScaleInvariant Feature Transform (SIFT). Scale-Invariant Feature Transform (SIFT) is an algorithm in Computer vision to detect and describe local features of images. This algorithm was published by $[3,4]$. The SIFT method has strong resistance to scaling, rotation, changes in image perspective, changes in lighting intensity and noise Digital image processing methods and artificial neural networks obtain faster measurement results compared to measurements in the Laboratory. So that the data can be directly used in the use of fertilizers to suit the needs of the soil without waiting several days.

In processing image data using the SIFT method, it provides benefits for nutrient measurements. Farmers usually use $\mathrm{N}, \mathrm{P}$ and $\mathrm{K}$ nutrient content in the soil to fertilize crops. The results of this SIFT research method can be used as a reference for fertilizing recommendations for the administration of nutrients $\mathrm{N}, \mathrm{P}$ and $\mathrm{K}$. 


\section{METHODOLOGY}

\subsection{System Analysis}

This Research Is Focused on The Texture Features of The Soil, The Pattern of These Features Will Be Processed by Artificial Neural Networks. Scale-Invariant Feature Transform Operation Is One of The Powerful Feature Extractors. That Is Because, The Operation Detects and Describes Local Features of An Image. Sift Has A Fairly Strong Resistance to Scaling, Rotation and Changes in Image Perspective. Effectively the Sift Method Has the Results of Analysis with High Accuracy $[3,4,5,6]$.

The results of system models that can predict nutrient levels from the texture characteristics of artificial neural networks are trained with the backpropagation algorithm. The principle works, the image that has been stored in a folder with labelled as needed to be extracted by Scaleinvariant feature transformation operations, so that the texture characteristics are obtained. These characteristics are used as input from trained neural network models $[7,8,9,10]$.

\subsection{System Design}

The design of system is explained in Figure 1, there is a process of training artificial neural network models on a computer. The training data is used for the training process which includes the pre-processing process, feature extraction using Scale-invariant feature transform operations, the results of the feature extraction will be input into a multilayer perceptron type artificial neural network that is trained by the backpropagation algorithm with laboratory test results as a target. The testing process used test data to see the performance of the system which includes the pre-processing process, feature extraction, and the results of the process will be entered a trained tissue model that predicts levels of nutrients nitrogen, phosphorus, and potassium.

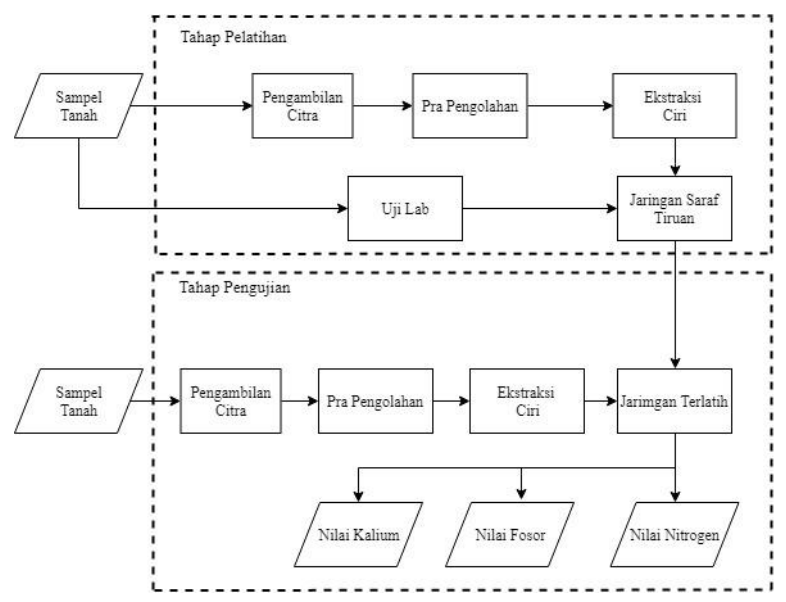

Fig. 1. Research Block Process

\section{3 Hardware}

The hardware in this study is a unified system arranged in such a way as to obtain a series of hardware needed. Figure 2 is a hardware design in the form of a tripod with the addition of PVC pipe joints to meet the height variation specifications ranging from $30 \mathrm{~cm}-110 \mathrm{~cm}$. The camera is placed on a smartphone holder that can be adjusted to take an angle, so that it meets shooting specifications ranging from $-30^{\circ}$ to $30^{\circ}$, in addition to that the hardware is equipped with a waterpass that is used for reference points to take angle variations.

Figure 2 Hardware Design The hardware design in this study is a unified system arranged in such a way as to obtain a series of hardware needed. Figure 2 is a hardware design in the form of a tripod with the addition of PVC pipe joints to meet the height variation specifications ranging from $30 \mathrm{~cm}-110 \mathrm{~cm}$. The camera is placed on a smartphone holder that can be adjusted to take an angle, so that it meets shooting specifications ranging from $-30^{\circ}$ to $30^{\circ}$, in addition to that the hardware is equipped with a water pass that is used for reference points to take angle variations.

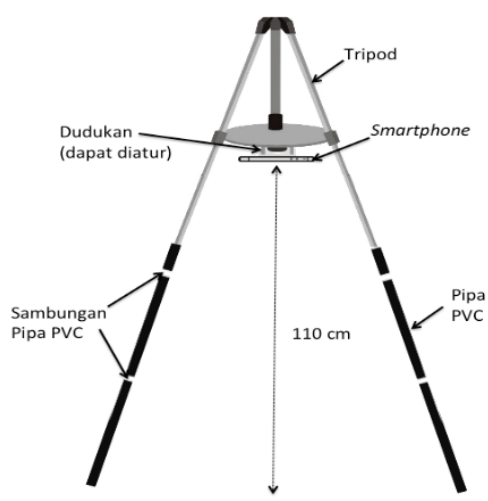

Fig. 2. Hardware Design

\subsection{Software}

Software design is a unified program that processes starting from the process of image capture, image data processing in the digital realm, and finally the prediction of nutrient levels using artificial neural networks. Figure 3 is an overall flow diagram of the system.

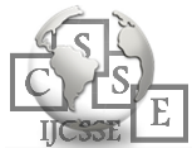




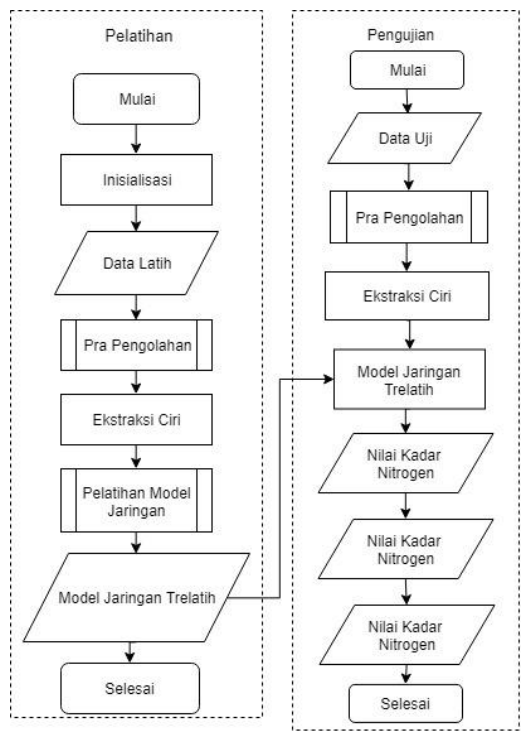

Fig. 3. Flowchart System

\section{RESULT AND ANALYSIS}

\subsection{Neural Network Parameters}

Artificial neural network parameters to be tested are the number of epochs, and the number of units in the hidden layer. Tests carried out variations on the epoch with units in the hidden layer at 40 units for Nitrogen, 44 units for Phosphorus and 34 units for Potassium.

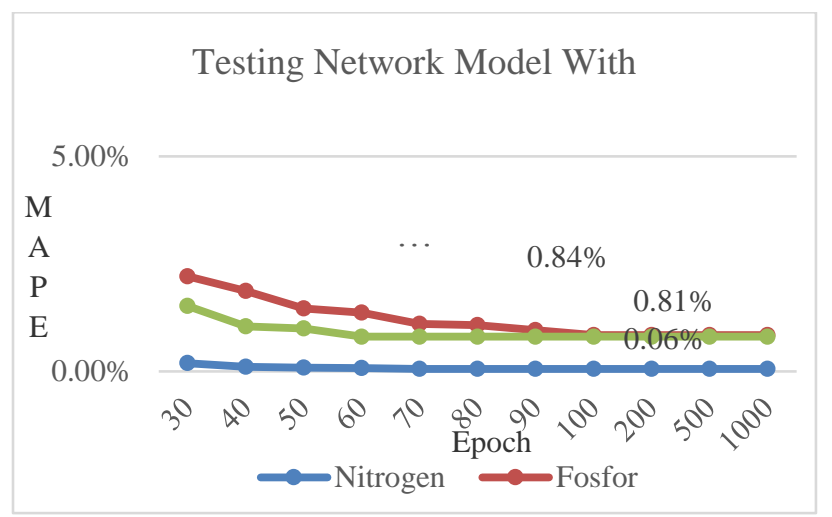

Fig. 4. Epoch variation

Fig.

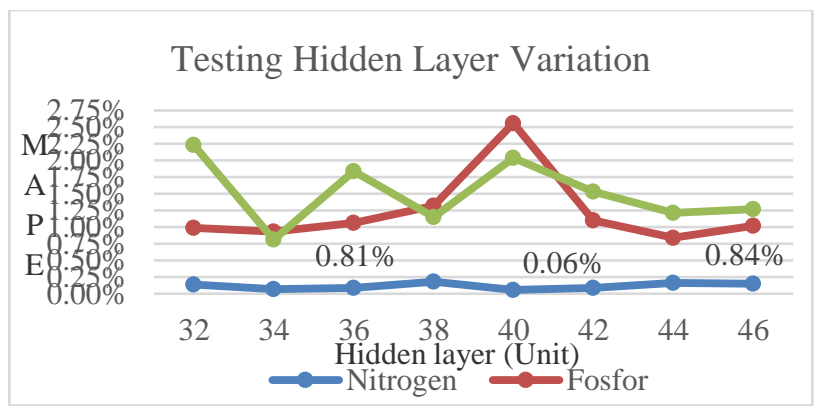

Fig. 5. Hidden layer variation

The results of the MAPE value experience a downward trend when the value of the epoch is higher, but the decrease in the value of the MAPE stops at epoch 100 to 1000 has a MAPE value which is $0.57 \%$ in Figure 4 . The results of each nutrient content will get levels nitrogen $(0.06 \%)$, phosphorus content $(0.84 \%)$ and potassium content $(0.81 \%)$. Testing on hidden layer unit variations is done by adjusting the learning rate values of 0.1 and 1000 epoch. The hidden layer unit tests on artificial neural network models start from 2 units to 100 units at intervals of 2 units. Figure 5 shows the hidden layer testing of 32 units of neural network models, 34 units, 36 units, 38 units, 40 units, 42 units, 44 units and 46 units.

\subsection{Variation of Training Data and Test Data}

Variation of training data and test data is done to find the pair of training data and test data on the composition of $90 \%$ of training data and $10 \%$ of test data. The test of the training data pair and test data used data at $50 \mathrm{~cm}$ and $0^{\circ}$ angle with a learning rate value of 0.1 , epoch 100,40 units for the nitrogen network model and 44 units for the phosphor network model, while 34 units for the potassium network model. Cross validation data pairs will be varied, so we find pairs that have the optimal MAPE value. The results of variations of data pairs can be seen in Table 1 
Table 1: Test Results Variations in Training Data Pairs and Test Data

\begin{tabular}{|l|l|l|l|}
\hline \multirow{2}{*}{ Testing } & \multicolumn{3}{|c|}{ AVG MAPE (\%) } \\
\cline { 2 - 4 } Bantul & \multicolumn{1}{|c|}{ N } & \multicolumn{1}{c|}{ P } & \multicolumn{1}{c|}{ K } \\
\hline Pogung & $\begin{array}{l}13,5 \\
3\end{array}$ & 48,87 & 85,66 \\
\hline Taman Tirto & $\begin{array}{l}16,0 \\
8\end{array}$ & 286,28 & 59,99 \\
\hline Palagan & 8,84 & 261,13 & 190,63 \\
\hline Pakem & 9,99 & 158,93 & 111,80 \\
\hline Mangunan & $\begin{array}{l}10,5 \\
9\end{array}$ & 51,48 & 201,11 \\
\hline Kalasan & 5,37 & 44,04 & 40,76 \\
\hline Godean & 5,58 & 57,89 & 75,85 \\
\hline Cangkringan & 6,48 & 102,41 & 150,96 \\
\hline Guwosari & 5,14 & 53,42 & 36,42 \\
\hline
\end{tabular}

The results of the test showed that the pair of test data in the Guwosari and Pogung areas had an average MAPE value for nitrogen levels $(5.14 \%)$, phosphorus levels $(41.07 \%)$, and potassium levels $(36.42 \%)$.

\subsection{Altitude and Angle Distance Testing}

Tests on the variation of distance and angle of image capture to get the network model at the distance and angle with the optimal mean absolute percentage error (MAPE) value. Data is taken to adjust the hardware specifications, namely the variation in the distance between $30 \mathrm{~cm}-110 \mathrm{~cm}$ with intervals of $20 \mathrm{~cm}$ and angles between $-30^{\circ}$ to $30^{\circ}$ with intervals of $10^{\circ}$. The test conditions use a learning rate value of $0.1,100$ epochs, and units in the hidden layer of 50 units.

The average results of the best distance measurements can be seen in Figure 6, the highest average accuracy (89.24\%) obtained at a height of $70 \mathrm{~cm}$ with a MAPE value of only $10.76 \%$. The lowest average MAPE value at a height of $70 \mathrm{~cm}$ compared to the average MAPE at a height of $30 \mathrm{~cm}, 50 \mathrm{~cm}, 90 \mathrm{~cm}$ and $110 \mathrm{~cm}$ so that it can be concluded that the optimal height to stabilize the soil image is $70 \mathrm{~cm}$ above the ground surface. The height of 70 is used for subsequent tests. In Figure 6, it is also seen that the $\mathrm{N}$ value has a relatively low MAPE average, only in the range of $3.59 \%$ to $6.65 \%$. $\mathrm{P}$ values have an average MAPE ranging from $9.22 \%$ to $47.15 \%$. $\mathrm{K}$ values have the largest average MAPE, ranging from $16.40 \%$ to $66.99 \%$

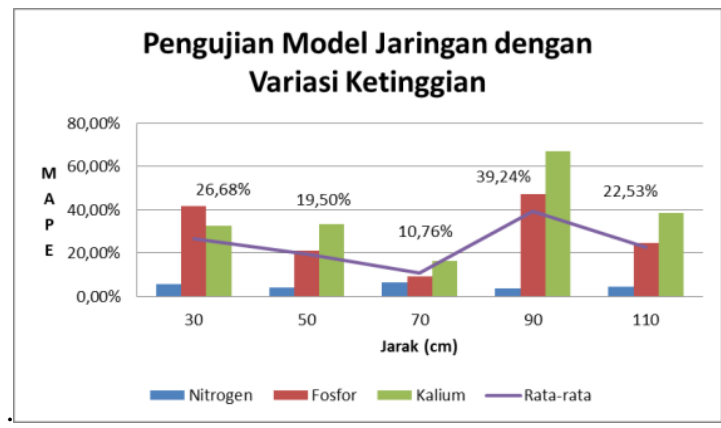

Fig. 6. The result of Testing Model on Height Variation

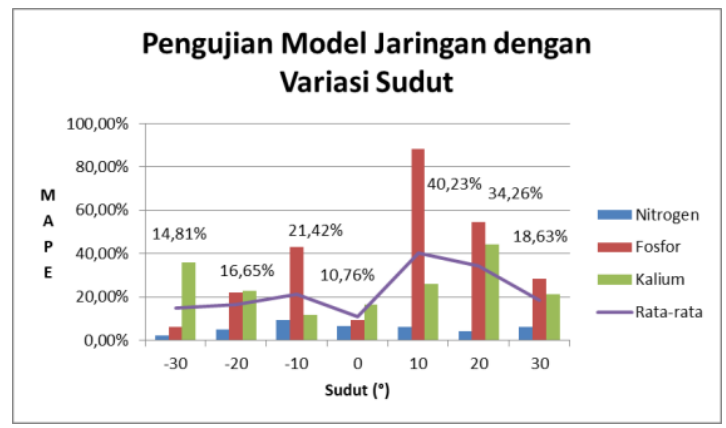

Fig. 7. The result of Testing Model on Angle Variation

The average results of the best distance measurements can be seen in Figure 6, the highest average accuracy $(89.24 \%)$ obtained at a height of $70 \mathrm{~cm}$ with a MAPE value of only $10.76 \%$. The lowest average MAPE value at a height of $70 \mathrm{~cm}$ compared to the average MAPE at a height of $30 \mathrm{~cm}, 50 \mathrm{~cm}, 90 \mathrm{~cm}$ and $110 \mathrm{~cm}$ so that it can be concluded that the optimal height to stabilize the soil image is $70 \mathrm{~cm}$ above the ground surface. The height of 70 is used for subsequent tests. In Figure 6, it is also seen that the $\mathrm{N}$ value has a relatively low MAPE average, only in the range of $3.59 \%$ to $6.65 \%$. P values have an average MAPE ranging from $9.22 \%$ to $47.15 \%$. $\mathrm{K}$ values have the largest average MAPE, ranging from $16.40 \%$ to $66.99 \%$. The results of the test presented in Figure 7 show that the MAPE value has increased at an angle of $0^{\circ}$ to $20^{\circ}$ and $0^{\circ}$ to $-20^{\circ}$, but at an angle of $20^{\circ}$ to $30^{\circ}$ and $-20^{\circ}$ to $30{ }^{\circ}$ the MAPE value has decreased. Tests of each nutrient obtained optimal average measurement results at an angle of $0{ }^{\circ}$ with MAPE values of nitrogen content (6.65\%), phosphorus content $(9.22 \%)$, and potassium levels $(16.40 \%)$, so the average is $10.76 \%$. In testing with variations in height from $30 \mathrm{~cm}$ to $110 \mathrm{~cm}$ with intervals of $20 \mathrm{~cm}$ and angle variations of $-30^{\circ}$ to $30^{\circ}$ with intervals of $10^{\circ}$ obtained an optimal height of $70 \mathrm{~cm}$ with an angle of $0^{\circ}$. 


\section{CONCLUSIONS}

Based on the test results of the NPK nutrient content determination system using Scale-Invariant Feature Transform (SIFT) and Backpropagation Neural Network with Artificial Neural Network parameters using hidden layers for each element including 40 units for $\mathrm{N}$ elements, 44 units for $\mathrm{P}$ elements and 34 units for the K. Epoch element used 100 and a minimum error of 0.000001 with a learning rate of 0.1 . Cross Validation results obtained areas that have the lowest average MAPE are Guwosari for $\mathrm{N}$ and $\mathrm{K}$ elements and Pogung for $\mathrm{P}$ elements with average MAPE values for nitrogen levels (5.14\%), phosphorus levels $(41.07 \%)$ and potassium levels $(36.42 \%)$. The accuracy of determining NPK nutrient levels using the SIFT method and Backpropagation Neural Network with Artificial Neural Network parameters of $72.46 \%$ includes $(94.86 \%)$ on the Nitrogen element, $(58.93 \%)$ on the Phosphorus element and $(63.57 \%)$ on the Potassium element. These results are obtained on image capture with an optimal height of 70 $\mathrm{cm}$ and an angle of $0 \mathrm{o}$.

\section{REFERENCES}

[1] Badan Penyuluhan dan Pengembangan SDM Pertanian, 2015. Pelatihan Teknis Budidaya Padi Bagi Penyuluh Pertanian dan Babinsa: pemupukan. Pusat Peltihan Pertanian, Jakarta.

[2] M. Hidayanto, 2014. "Analisis Tanah Tambak Sebagai Indikator Tingkat Kesuburan Tambak". [Online]. Available:

http://repository.pertanian.go.id/handle/123456789/2039 [Accesed: 17 Maret 2018]

[3] Lowe, D.G. 1999. Object Recognition from Local Scale-Invariant

[4] Features, Canada, pp. 1, 2, 3

[5] Lowe, D.G, 2004. Distinctive image features from scale-invariant keypoints. International Journal of Computer Vision.

[6] Kumalasanti et al, 2015. Identifikasi Tanda Tangan Statik Menggunakan Jaringan Saraf Tiruan Backpropagation Dan Wavelet Haar. Simposium Nasional. Yogyakarta.

[7] Koeshardianto, 2014. Pencocokan Obyek Wajah dengan Metode SIFT (Scale Invariant Feature Transform). Jurnal Ilmiah NERO Vol. 1 No. 1. Madura.

[8] Y. P. Wiharja,2014. "Pemrosesan Citra Digital untuk Klasifikasi Mutu Buah Pisang Menggunakan Jaringan Saraf Tiruan" IJEIS(Indonesian J. Elektron.Instrum.Syst.), Vol.4, No.1, Apr. 2014, pp. 57 68. [Online]. [Accesed: 17 April 2017]

[9] Hermantoro, 2011. Aplikasi pengolahan Citra Digital dan Jaringan Saraf Tiruan Untuk Prediksi Kadar Bahan Organik Dalam Tanah. [Online]. Available: http://www.instiperjogja.ac.id/download/jurnal/CITRAJST-BO.PDF. [Accesed: 17 Maret 2017]
[10] M. B. Bodaghabadi, J. M. Casasnovas, M. H. Salehi, J. Mohammadi, I. E. Borujeni, N. Toomanian, and A. Gandomkar, 2015, Digital Soil Mapping Using Artificial Neural Networks and Terrain-Related Attributes, Pedosphere.25(4): 580-591.. [Online]. Available: https://doi.org/10.1016/S10020160(15)30038-2 [Accesed: 4 Juli 2017]

[11] H. Ramchoun, M. A. J. Idrissi, Y. Ghanou, M. Ettaouil, 2015, Multilayer Perceptron: Architecture Optimization and Training, Pedosphere.25(4): 580-591. [Online]. Available: https://doi.org/10.1016/S10020160(15)30038-2 [Accesed: 10 Mei 2018]

[12] Kapur, S., dan Thakkar, N., 2015. Mastering OpenCV Android Application Programming: Master the art of implementing computer vision algorithms on Android platforms to build robust and efficient applications. Packt Publishing Ltd, Birmingham, pp. 1 